EVOLUTIONARY

BIOLOGY

\section{Trends in development of diatom flora from sub-recent lake sediments of the Lake Bolshoy Kharbey (Bolshezemelskaya tundra, Russia)}

\author{
Olga Palagushkina1, Larisa Nazarova ${ }^{1,2,3}$, and Larisa Frolova ${ }^{1}$ \\ ${ }^{1}$ Kazan (Volga Region) Federal University, Kremlyovskaya Str., 18, \\ Kazan, 420008, Russian Federation \\ 2University of Potsdam, Institute of Geosciences, Karl-Liebknecht-Str., 24-25, \\ Potsdam-Golm, 14476, Germany \\ ${ }^{3}$ Alfred Wegener Institute, Helmholtz Centre for Polar and Marine Research, \\ Telegrafenberg A43, Potsdam, 14473, Germany \\ Address correspondence and requests for materials to Olga Palagushkina, \\ opalagushkina@mail.ru
}

\begin{abstract}
We studied diatom assemblages of the proglacial arctic lake Bolshoy Kharbey (Bolshezemelskaya tundra, Russian Arctic) from a short sediments core covering last ca. 200 years. In total, 121 taxa from 2 classes, 5 orders, 18 families, and 50 genera were identified. The diatom flora included species with mainly cosmopolitan distribution. The assemblages were dominated by alkaliphilic benthic diatoms preferring standing - flowing waters, indifferent to salinity and moderate temperature conditions. The main changes in diatom assemblages took place at ca. 1870 and 1980. After 1870, which can be attributed to the end of the Little Ice Age, the species richness rose, especially of planktonic centric and small penate diatoms. This rise of diatom diversity took place most probably in response to climate warming, related to prolongation of the growing season and period of open water. A negative trend in the evenness of the diatom assemblages during the last decades can be seen as an early-warning signal indicating a decrease of stability of the lake ecosystem.
\end{abstract}

Keywords: diatoms, Lake Bolshoy Kharbey, Russian Arctic, climate change.

Citation: Palagushkina, O., Nazarova, L., and Frolova, L. 2019. Trends in development of diatom flora from sub-recent lake sediments of the Lake Bolshoy Kharbey (Bolshezemelskaya tundra, Russia). Bio. Comm. 64(4): 244-251. https://doi. org/10.21638/spbu03.2019.403

Author's information: Olga Palagushkina, $\mathrm{PhD}$, Senior Researcher, orcid.org/00000002-8131-0216; Larisa Nazarova, PhD, Senior Researcher, orcid.org/0000-0003 4145-9689; Larisa Frolova, PhD, Senior Researcher, orcid.org/0000-0001-8505-0151

Manuscript Editor: Pavel Skutschas, Department of Vertebrate Zoology, Faculty of Biology, Saint Petersburg State University, Saint Petersburg, Russia

Received: October 18, 2019;

Revised: December 2, 2019;

Accepted: December 3, 2019;

Copyright: @ 2019 Palagushkina et al. This is an open-access article distributed under the terms of the License Agreement with Saint Petersburg State University, which permits to the authors unrestricted distribution, and self-archiving free of charge.

Funding: This study was supported by the grant of the Russian Science Foundation (Grant 16-17-10118).

Competing interests: The authors have declared that no competing interests exist.
Climate change in polar regions is among the largest and most rapid of any regions on Earth and will cause major ecological impacts (Fritz et al., 2016; Palagushkina et al., 2017a). According to the scientific report of the Arctic Council and the International Arctic Science Committee (IASC), more observations are urgently required to better understand ecosystem responses to climate change in the Arctic (Douglas et al., 1994; ACIA, 2005). The sensitivity of arctic ecosystems to temperature variations makes them especially important locations for investigation of past and present climate-related ecological changes (Nazarova et al., 2013; Frolova, 2018; Plikk et al., 2019). Therefore, lake sediments and permafrost records can provide unique data on recent biotic changes in remote areas where expensive long-term monitoring has not been possible (Frolova et al., 2017a, 2019; Wetterich et al., 2018). The dominant response of arctic ecosystems and species to climate change is very likely to be relocation rather than adaptation of single species (Frolova et al., 2013, 2017b; Ibragimova et al, 2016), but knowledge of the entire spectrum of responses of the most important indicator group of water communities, including diatom algae (Palagushkina et al., 2012, 2017b; Hoff et al., 2015; Solovieva et al., 2015), is essential for assessment of the ecological state of surface waters (Nazarova et al., 2004, 2017a) and for exploration of natural successions under the influence of natural and anthropogenic factors (Subetto et al., 2017; Syrykh et al., 2017).

\section{Introduction}




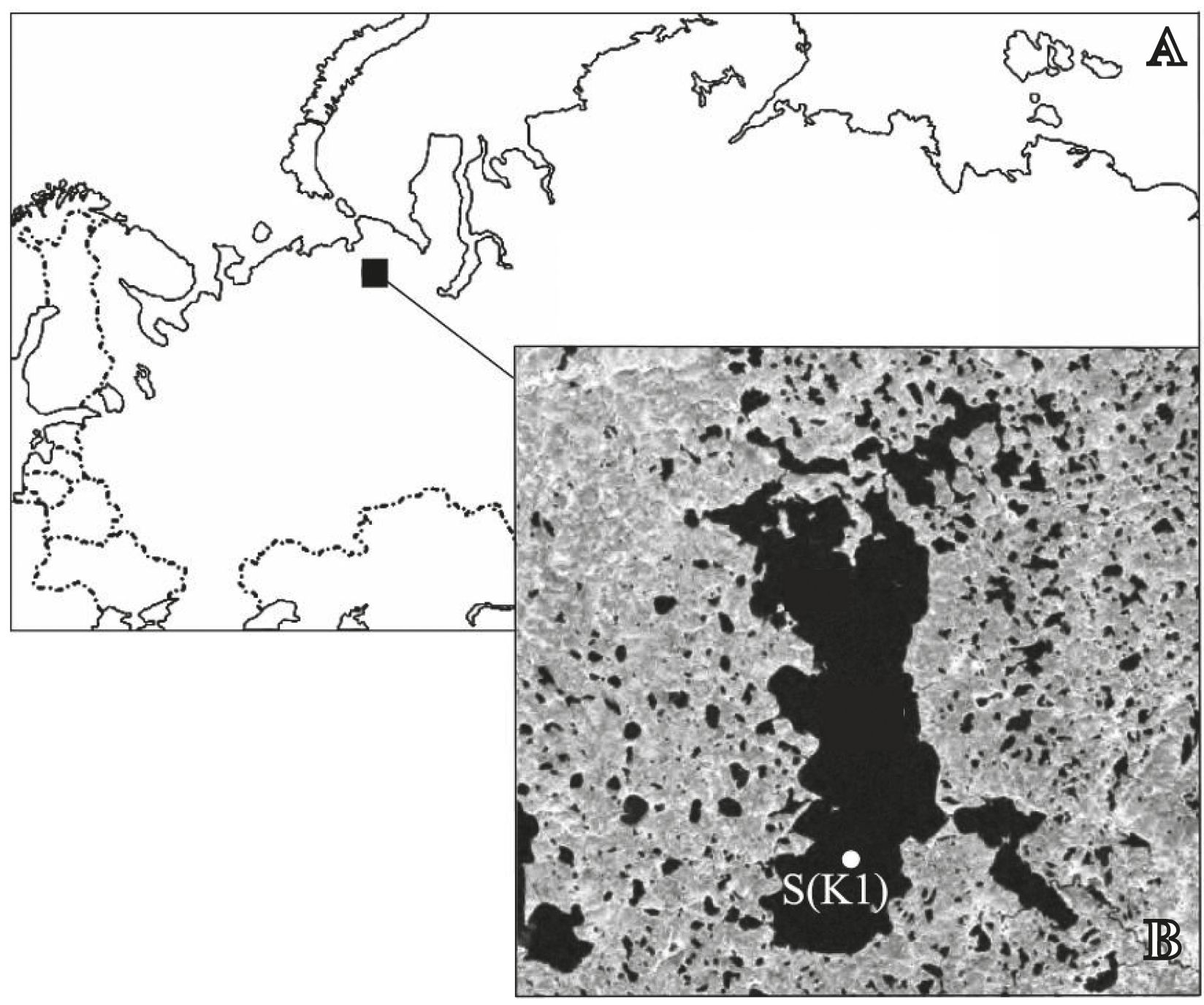

Fig. 1. Location of the study area (A) and the sampling site $S(K 1)$ at the lake Bolshoy Kharbey (B).

Studies of the lakes from the Canadian Arctic, Scandinavia and Fennoscandia showed that the changes in their ecosystems are largely linked to global warming during the last 150-200 years (Smol et al., 2005). However, there are only few recent studies which investigated environmental changes in lakes from northeastern European Russia (e.g., Solovieva et al., 2005, 2008; Nazarova et al., 2017b). The aim of this work was to study the taxonomic composition of diatom flora of the Lake Bolshoy Kharbey (Bolshezemelskaya tundra, Russian Arctic) and to identify changes in the structure of diatom assemblages under the changing climatic conditions of the sub-recent time.

\section{Study area}

The research area covers eastern part of the Bolshezemelskaya tundra in the European West tundra province within the circumpolar tundra region in the subzone of shrub tundra (Teteryuk, 2012) (Fig. 1).
The relief is hilly, with a maximum height of $230 \mathrm{~m}$ above sea level. The climate of the region is severe and sharply continental, which is associated with deep and prolonged freezing of the soil and development of cryogenic processes (Vlasova, 1976). Winter lasts 8-9 months. The coldest month is January with a minimum temperature of $-55^{\circ} \mathrm{C}$; the warmest month is July with a maximum temperature of $31^{\circ} \mathrm{C}$. The annual rainfall varies between 370 and $395 \mathrm{~mm}, 60 \%$ of which falls during the summer months, with a maximum in August (Mukhin et al., 1964). Over the past decades, the climate continentality in the research region has increased: the difference between the warmest and the coldest months has increased by $1.4^{\circ} \mathrm{C}$. In $1961-1990$ January became colder by ca. $0.4^{\circ}$ $\mathrm{C}$, and July became warmer by ca. $1^{\circ} \mathrm{C}$ compared with observations over the proceeding 110 years (Fefilova, 2006).

Kharbey Lakes System has a glacial origin and includes three inter-connected large lakes - Golovka, Bolshoy Kharbey, Maliy Kharbey - and many small lakes connected by channels (Fefilova, 2006). The study lake, 


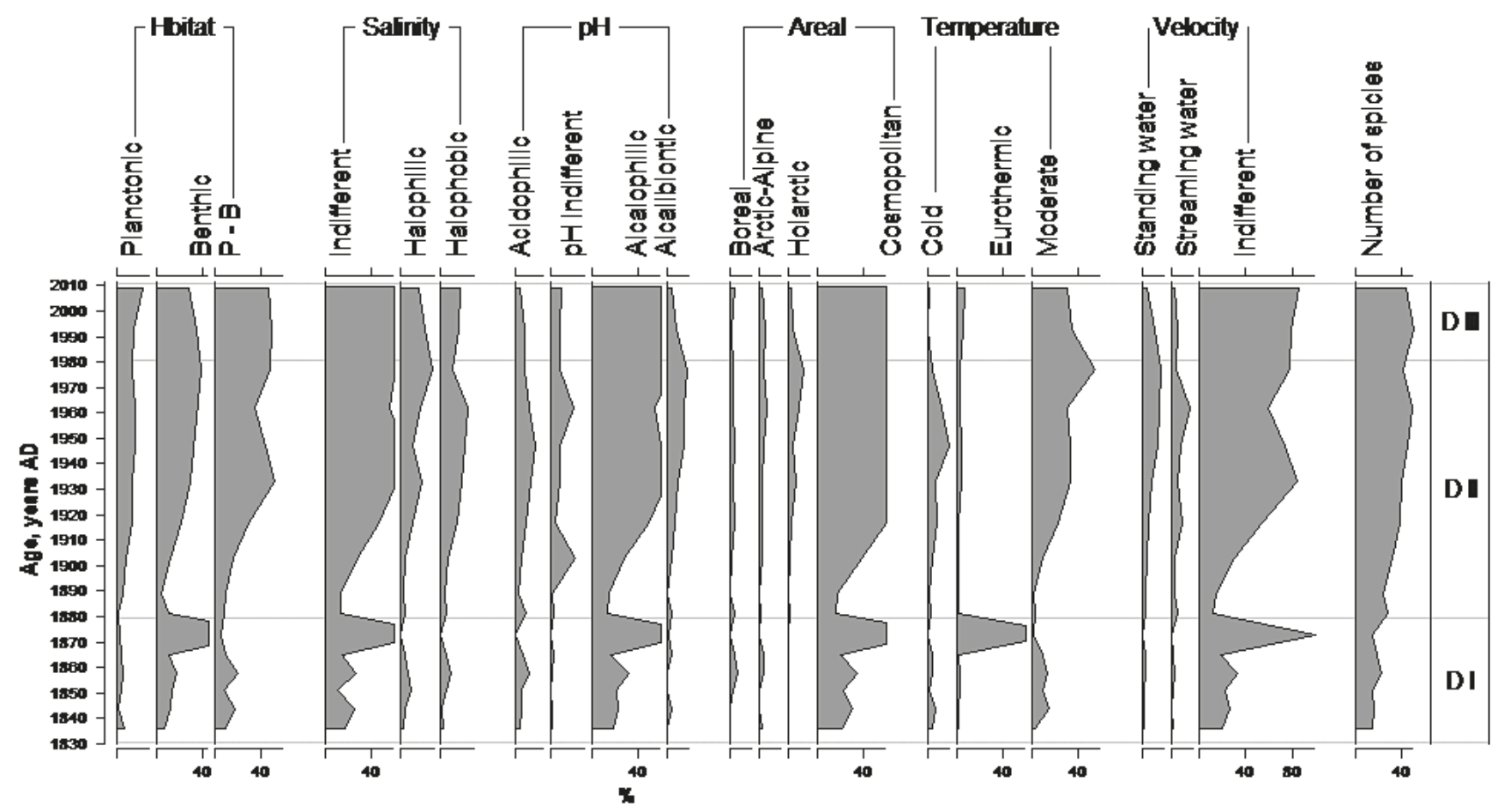

Fig. 2a. Distribution of diatoms in the short sediment core of Lake Bolshoy Kharbey, Shannon diversity (H) and Pielu Evenness (I) indices; D I - D III - statistically significant zones. Species with $\geq 2 \%$ of valves per sample are shown in this figure.

Bolshoy Kharbey (LBK), has a catchment area of $57.3 \mathrm{~km}^{2}$. The shoreline is swampy. The lake area is $21.3 \mathrm{~km}^{2}$; maximum and average depths are 18.5 and $4.6 \mathrm{~m}$, respectively (Vlasova, 1976; Fefilova, 2006). Earlier studies have shown insignificant salinity of the lake water, and predominantly hydrocarbon-calcium composition of water with low color, neutral $\mathrm{pH}$, and low nutrient content (Baturina et al., 2012). During the study period water in LBK had low conductivity $\left(27 \mu \mathrm{S} \mathrm{cm}^{-1}\right)$ and was circum-neutral $(\mathrm{pH}=$ 7.1-7.3). Water transparency varied from 2.7 to $2.9 \mathrm{~m}$.

\section{Material and Methods}

In summer 2012, a short sediment core $(26 \mathrm{~cm})$ was taken in the southern part of LBK $\left(67^{\circ} 31.832^{\prime} \mathrm{N}, 062^{\circ}\right.$ $52.669 \mathrm{E}$ ) from the depth of $6 \mathrm{~m}$ using a UWITEC sampler. The core was cut into $1 \mathrm{~cm}$ intervals for further laboratory analysis. The age-depth model for the core is based on results of ${ }^{210} \mathrm{~Pb}$ analysis performed at Geochronology Laboratory of St. Petersburg State University and made with the Bacon 2.2 package (Blaauw and Christen, 2011) of R software (R Core Team, 2012). All the dates in the paper are expressed as years $\mathrm{AD}$.

Processing of sediment samples for diatom analysis was performed using the water bath method (Battarbee, 1986) in the laboratory of the Alfred Wegener Institute, Helmholtz Centre for Polar and Marine Research (Pots- dam, Germany). Diatom slides were mounted using Naphrax. Diatoms were identified at the lowest possible taxonomic level following mainly Krammer and LangeBertalot (1986-1991), in accordance with modern taxonomy as given in the Algaebase database (Guiry and Guiry, 2015) and classification of diatoms used in Russia (Glezer et al., 1988) with the latest revisions (Genkal et al., 2013; Guiry and Guiry, 2019, http://www.algaebase. org/browse/taxonomy/?id=77640).

We identified and counted 300 to 500 valves per sample under Axioplan Zeiss light microscope equipped with an oil-immersion objective. The total number of valves was taken as $100 \%$. We defined taxa with abundances of $\geq 10 \%$ and $\geq 5 \%$ as dominants and subdominants, respectively (Palagushkina et al., 2012). Biogeographical and ecological characteristics of the taxa with respect to preferences of habitat, $\mathrm{pH}$, water salinity, as well as changes in the ice cover duration and the spring/autumn turbulence period were described following Davydova (1985), Van Dam et al. (1994), Fallu et al. (2000), Barinova et al. (2006) and other sources from case studies.

To assess the species diversity and evenness of diatom communities, we calculated the Shannon and Pielou indices (Pielou, 1966; Shannon and Weaver, 1963). The stratigraphic diagram was constructed in the C2 program 1.7.7 (Juggins, 2007); zonation was performed using cluster analysis performed in the program PAST 2.07 (Hammer et al., 2001). 


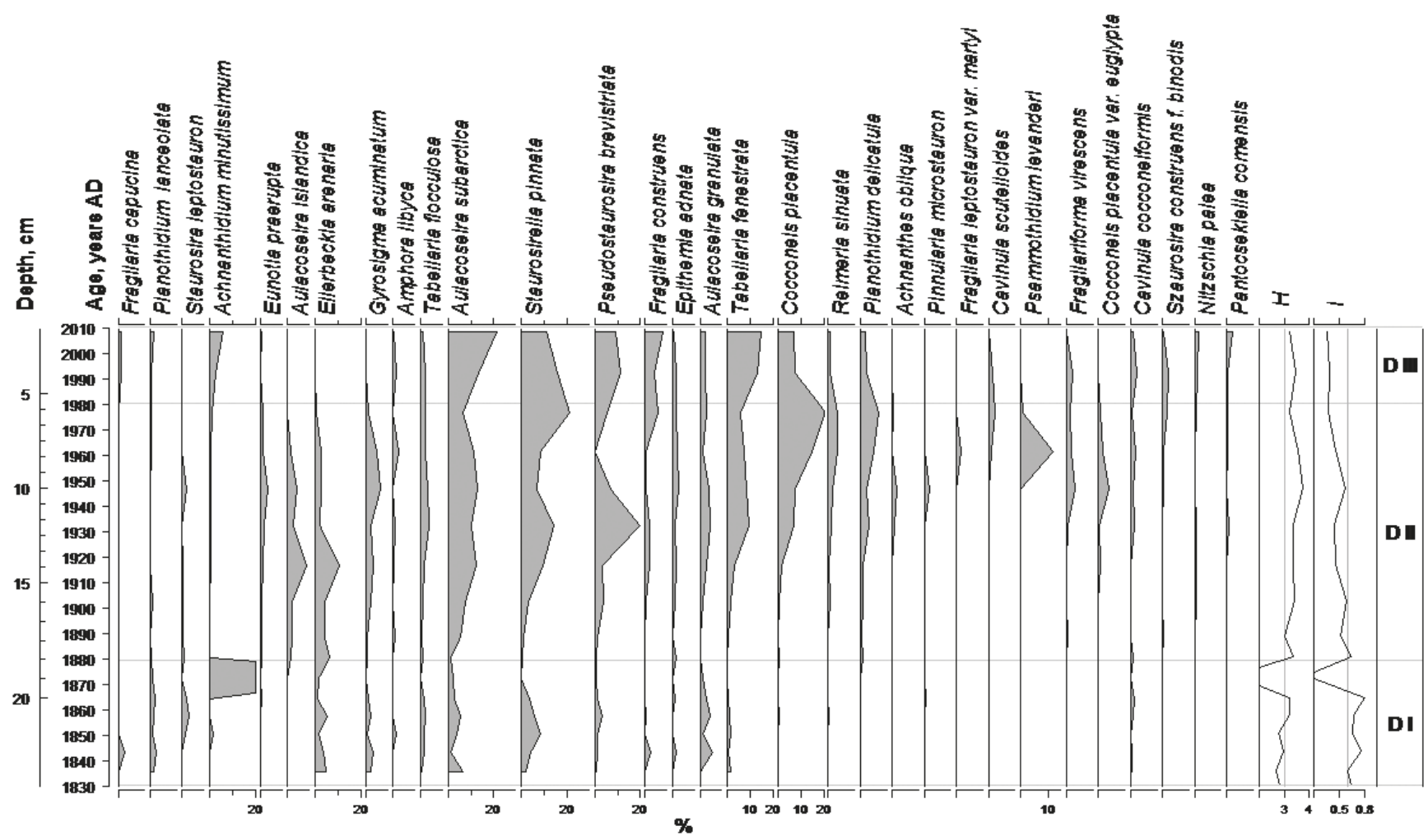

Fig. 2b. Distribution of ecological groups of diatoms in sediments of Lake Bolshoy Kharbey with regard to habitat type, salinity, pH, geographical distribution, temperature, and water flow.

\section{Results}

Altogether, in sediment samples from LBK we identified 122 diatom taxa belonging to 2 classes, 5 orders, 18 families and 50 genera (Table 1).

In relation to habitat, benthic species were the most frequent in the flora ( 74 species or $60.7 \%$ of the taxonomic richness), 28 species were planktonic-benthic ( $23 \%$ of the taxonomic richness), 5 planktonic species (4.1\%), and 1 epiphytic species were found $(0.8 \%)$.

In relation to salinity the diatom flora of LBK was dominated by oligohalobic taxa (105 species, or $86 \%$ of the taxonomic richness), the majority of which constituted indifferent species (74 species or $70.5 \%$ ). We found 17 halophobic (16.1\%) and 13 hallophilic (12.4\%) species. Mesohalobic flora was represented by 3 species (2.5\%): Navicula digitoradiata, Surirella amphioxys, and Surirella ovalis (Table 1).

In relation to $\mathrm{pH}$, the majority of species preferred alkaline waters (61 species, or $50 \%$ of the taxonomic richness). Among them 51 species (41.8\%) were alkaliphiles and $10(8.2 \%)$ were alkalibionts. Flora indifferent to $\mathrm{pH}$ was represented by 25 species $(20.5 \%)$, and only 15 acidophilic species were found (12.3\%).

By geographical distribution, most of the species could be attributed to cosmopolitan species (73 species, or $59.8 \%$ of the taxonomic richness), 11 (9\%) have bo- real distribution, 9 (7.4\%) arctic-alpine, and 1 species, Planothidium delicatulum, has Holarctic distribution $(0.8 \%)$.

In relation to water temperature, information is available for 30 species that we found in LBK: 22 of them prefer moderate conditions, 4 species are cold-stenothermic, 3 are eurythermic, and 1 species is warm-water (Planothidium lanceolatum).

With respect to the water-flow factor, information is available for 87 species, of which species of stagnantflowing (45) and flowing water (23) constituted the majority. Flora of stagnant water was represented by 18 species. One aerophilic species, Pinnularia borealis, was also found.

The diatom stratigraphy from LBK was split into 3 assemblage zones (D I - D III; Fig. 2 and 3).

D I (1829-1880; $25-18 \mathrm{~cm})$. The number of species in sediment layers from this time interval varied from 15 to 23 , the Shannon species diversity index ranged from 0.45 to 2.7 and evenness varied from 0.11 to 0.64 with the lowest values of all parameters at the top of the zone in ca. 1870. The diatom flora was represented by cosmopolitan benthic and planktonic-benthic alkaliphilic species, indifferent to water salinity, preferring moderate temperature conditions and stagnant waters (Fig. 2, 3). Presence of the cold-stenothermic Gyrosigma acuminatum in the species composition until 1870 sug- 
gests a moderate to cool climate at this time. Dominance of benthic and planktonic-benthic diatoms may be associated with a low water level in the lake that started to rise after 1870 (Fig. 3). A strong dominance of Achnanthidium minutissimum ( $92 \%$ of the total number of valves) at ca. 1870 reflects an increase of water flow.

D II $(1880-1962 ; 18-6 \mathrm{~cm})$. The number of species ranged from 14 (ca. 1890) to 49 (1950). The Shannon index ranged from 2.5 to 3 . 3. The Pielou index gradually declines towards the top of the zone from 0.65 to 0.52 , indicating a lower level of evenness of the diatom communities (Fig. 2b).

At the beginning of this time interval, after 1880 we observed some decrease in the proportion of benthic diatoms and a gradual increase in the share of planktonic and planktonic-benthic species (Fig. 3). The planktonic subdominant species Aulacoseira islandica reached the highest abundance in ca. 1917, when planktonic Aulacoseira subarctica and planktonic-benthic Ellerbeckia arenaria dominated the diatom assemblages. We observed an increase as well in the share of halophobic species (from 0.2 to $23.7 \%$ ). These floristic changes confirm that in ca. 1870 the water level in the lake started to rise. We observed an increase of the cold-stenothermic species in ca. 1950 (Fig. 3), like Gyrosigma acuminatum and Eunotia praerupta, which indicates some cooling.

D III (1977-2009; 4-0 cm) The upper part of the core is characterized by high species richness (4150 species), moderate Shannon's diversity (2.74-2.95) and lower evenness of diatom assemblages (0.35-0.38) than in D II (Fig. 2). High taxonomic richness in combination with low evenness indicates that the diatom assemblages are dominated by only a few species, and the other species remain at low abundances. There is a consistent increase in the proportion of planktonic and planktonic-benthic species and an increase of the standing-flowing water taxa in D III (Fig. 3). Aulacoseira subarctica (6-21\%), Tabellaria fenestrata (5-14.8\%), Cocconeis placentula (6-20.3\%), Pseudostaurosira brevistriata (5-20\%) and Staurosira construens (5.8-7.7\%) are dominant. This reflects a further rise of the water levels. The reappearance of the benthic species Achnanthidium minutissimum among subdominant species probably can reflect spreading of the lake littorals. A decrease of halophilic species reflects a decrease in mineralization.

\section{Discussion}

Our investigation has shown high species richness of diatoms in the investigated proglacial lake Bolshoy Kharbey, Bolshezemelskaya tundra, Arctic Russia. During the last 200 years the species richness rose. During the last ca 30-40 years it was a negative trend in the evenness (or rise of the dominance) of the diatom assemblages, which can be seen as a decrease of the stability of the lake ecosystem (Pielou, 1966).
Previous studies have shown that phytoplankton of the lakes in the Bolshezemelskaya tundra is characterized by a high species richness of diatoms. Especially taxonomically rich are deep glacial lakes with good water exchange (Stenina and Getsen, 1975; Stenina, 1978, 2009). Typical for phytoplankton of such lakes is a low diversity of planktonic, especially centric diatoms, frequent occurrence of periphytic and phytobenthic species as a result of intensive mixing of the water columns. The main role in diatom assemblages of the glacial lakes is played by species from the genera Aulacoseira, Asterionella, Tabellaria. The genera Cyclotella and Stephanodiscus are less represented (Stenina, 2009).

Earlier hydrobiological studies on LBK revealed 146 diatom taxa (Stenina, 2009). The diatom flora of the lake was mainly formed by benthic and periphytic species. Planktonic species accounted only for about $9 \%$ of the total number of species. In accordance with our study, Aulacoseira islandica, Aulacoseira subarctica, Asterionella formosa and Tabellaria fenestrata were described as dominants. A relatively high proportion of alkaliphilic diatoms was found in LBK in comparison with other lakes of the Bolshezemelskaya tundra. The proportion of boreal species in LBK was higher than the share of Arctic-alpine species (Stenina, 2009). These two features of the modern phytoplankton remain characteristic of the fossilized diatom assemblages of the lake during the last 200 years.

The taxonomic composition and richness of fossilized diatoms from the investigated core demonstrated high similarity to the data obtained from studies of the modern phytoplankton of the lake. Benthic and planktonic-benthic species dominated the assemblages during the last ca. 200 years. The share of planktonic species was as low as $4 \%$ on average, but it steadily increased towards the modern time, reflecting increasingly rising water-flow in the lake system, most probably caused by warming of the climate.

However, during the last ca. 200 years diatom assemblages of the Bolshoy Kharbey Lake underwent some transformations in response to changing environment. We distinguished three intervals characterized by different complexes of diatoms. As a reflection of the increasing warming of the environment and infilling of the lake that started after ca. 1870, the proportion of planktonic species (Aulacoseira subarctica, Ellerbeckia arenaria, Staurosirella pinnata, Cocconeis placentula, Pseudostaurosira brevistriata, Tabellaria fenestrata) increased, and increased further after 1980 (Fig. 3). A strong dominance of Achnanthidium minutissimum around ca. 1870 reflects an increase of water flow, probably in response to warming associated with the end of the Little Ice Age (LIA) in this region at this time (Solovieva et al., 2005). Changes in the species composition and complex of dominants reflect the ongoing processes of lake level rise associated with the influx of meltwater 
from the slopes of the Polar Urals and decrease of the total mineralization of the water.

Investigations of the other lakes from the Bolshezemelskaya tundra, also unaffected by direct anthropogenic impact, have shown a sufficient increase in the proportion of planktonic centric diatoms since 1970 (Solovieva at al., 2005, 2008). This trend reflects climate warming and the associated increase in the period of open water, contributing to the development of planktonic centric diatoms from the genus Aulacoseira. Species from the genus $\mathrm{Au}$ lacoseira require a sufficient amount of silicon for normal development, which becomes available only under a good mixing of the water column (Ruhland and Smol, 2005). The species Pseudostaurosira brevistriata and Staurosirella pinnata became dominant after 1870, as they were the first to inhabit the carbonate-rich waters of the recently thawed areas (Puusepp et al., 2010; Rouillard et al., 2012). The dominance of the Staurosirella pinnata also reflects an increase in paleotemperatures and climate warming (Weckstrom et al., 1997; Kumke et al., 2004). The dominance of Tabellaria fenestrata may be associated with a further increase of the water level in the lake due to climate warming (Trifonova and Afanasyeva, 2008).

\section{Conclusions}

Our study revealed several trends in the composition of diatom flora in Lake Bolshoy Kharbey during ca. 200 years in response to changing environmental conditions in the region of Bolshezemelskaya tundra, Russian Arctic. The strongest shift in diatom assemblages was observed around ca. 1870 and can be associated with the end of the LIA, related climate warming and prolongation of the open water period. The growth of diatom species richness and increase in abundances of planktonic centric and small penate diatoms can be related to the rise of the water level in the lake. A negative trend in the evenness (or rise of the dominance) of the diatom assemblages can be seen as an early-warning signal of a decrease of stability of the lake ecosystem.

\section{Acknowlegments}

We thank all our Russian colleagues who helped us during fieldwork. Our sincere thanks to the anonymous reviewers for their valuable comments. This study was supported by the grant of the Russian Science Foundation (Grant 16-17-10118).

\section{References}

ACIA 2005. Impacts of Warming Arctic: Arctic Climate Impact Assessment. Cambridge University Press.

Barinova, S. S., Medvedeva, L. A., and Anisimova, O. V. 2006. Biological diversity of algae-environmental indicators. 498 pp. Pilies Studio, Tel Aviv. (In Russian)

Barinova, S. S., Medvedeva, L. A., and Anisimova, O. V. 2006. Biodiversity of algae-indicators of the environment. Pilies Studio, Tel Aviv. (In Russian)
Battarbee, R.W. 1986. Diatom analysis: pp. 527-570 in B. E. Berglund (ed.), Handbook of Holocene Paleoecology and Paleohydrology, Wiley, Sons, London.

Baturina, M. A., Loskutova, O. A., Fefilova, E. B., and Khokhlova, L. G. 2012. Zoobenthos of Bolshoy Harbey Lake (Bolshezemelskaya tundra): current status and analysis of retrospective data. Bulletin of the Komi Scientific Center, Ural Branch of the Russian Academy of Sciences 4:21-29. (In Russian)

Blaauw, M. and Christen, J. A. 2011. Flexible paleoclimate agedepth models using an autoregressive gamma process. Bayesian Analysis 6(3):457-474. https://doi.org/10.1214/ $\mathrm{ba} / 1339616472$

Davydova, N. N. 1985. Diatoms as indicators of natural conditions of water bodies in Holocene. 244 pp. Nauka, Leningrad. (In Russian)

Douglas, M. S. V., Smol, J. P., and Blake, W. 1994. Marked post18th century environmental change in high Arctic ecosystems. Science 266:416-419. https://doi.org/10.1126/ science.266.5184.416

European Diatom Database http://craticula.ncl.ac.uk/Eddi/jsp

Fallu, M. A., Allaire, N., and Pienitz, R. 2000. Freshwater diatoms from northern Québec and Labrador (Canada). Bibliotheca Diatomologica. Gebr. Borntraeger, Berlin, 45:1-200.

Fefilova, E. 2006. Zooplankton and meiobenthic crustaceans of Kharbey Lakes. Bulletin of Institute of Biology. 10:7-11. (In Russian)

Fritz, M., Wolter, J., Rudaya, N., Palagushkina, O., Nazarova, L., Obu, J., Rethemeyer, J., Lantuit, H., and Wetterich, S. 2016. Holocene ice-wedge polygon development in the northern Yukon, Canada. QSR 147:279-297. https://doi. org/10.1016/j.quascirev.2016.02.008

Frolova, L., Nazarova, L., Pestryakova, L., and Herzschuh, U. 2013. Analysis of the effects of climate-dependent factors on the formation of zooplankton communities that inhabit arctic lakes in the Anabar River Basin. Contemporary Problems of Ecology 6(1):1-11. https://doi. org/10.1134/S199542551301006X

Frolova, L. A., Ibragimova A. G., Ulrich M., and Wetterich S. 2017a. Reconstruction of the history of a thermokarst lake in the Mid-Holocene based on an analysis of subfossil Cladocera (Siberia, Central Yakutia). Contemporary Problems of Ecology 10(4):423-430. https://doi. org/10.1134/S1995425517040023

Frolova, L., Nazarova, L., Zinnatova, E., Frolova A., and Herzschuh, U. 2017b. Cladocera remains from sediments of thermokarst lakes of north-central Siberia (Russia). 17th International Multidisciplinary Scientific GeoConference SGEM 2017, Conference Proceedings 17(51):211-218. https://doi.org/10.5593/sgem2017/51/S20.028

Frolova, L. A. 2018. Cladocera from bottom deposits as an indicator of changes in climate and ecological conditions. IOP Conference Series: Earth and Environmental Science. 107(1): 012084. https://doi.org/10.1088/17551315/107/1/012084

Frolova, L. A., Nigmatullin N. M., Frolova A. A., and Nazarova L. B. 2019. Findings of Phreatalona protzi (Hartwig, 1900) (Cladocera: Anomopoda: Chydoridae) in Russia. Invertebrate Zoology 16(2):200-210. https://doi. org/10.15298/invertzool.16.2.07

Genkal, S. I., Kulikovsky, M. S., Mikheeva, T. M., Kuznetsova, I. V., and Lukyanova, E. V. 2013. Diatoms of plankton of Svisloch River and its reservoirs. 236 pp. Scientific World, Moscow. (In Russian)

Glezer, Z. I., Karaeva, N. I., Makarova, I. V. et al. 1988. Classification of diatoms. In Diatoms of the USSR (fossil and modern) Leningrad. 2(1):31-35. (In Russian) 
Guiry, M. D. and Guiry, G. M. 2015. AlgaeBase. World-wide electronic publication, National University of Ireland, Galway http://www.algaebase.org

Guiry, M. D. and Guiry, G. M. 2019. AlgaeBase. World-wide electronic publication, National University of Ireland, Galway. https://www.algaebase.org

Hammer, Ø., Harper, D. A. T., and Raan, P. D. 2001. PAST: Palaeontological statistics software package for education and data analysis. Palaeontologia electronica 41:9.

Hoff, U., Biskaborn, B. K., Dirksen, V., Dirksen, O., Kuhn, G., Meyer, H., Nazarova, L., Roth, A., and Diekmann, B. 2015. Holocene environment of Central Kamchatka, Russia: Implications from a multi-proxy record of Two-Yurts Lake. Global and Planetary Change. 134:101-117. https:// doi.org/10.1016/j.gloplacha.2015.07.011

Ibragimova, A. G., Frolova, L. A., and Grekov, I. M. 2016. Results of subfossil Cladocera (Branchiopoda, Crustacea) analyses from bottom deposits of Lake Antyukh-Lambina (Kola Peninsula, Murmansk region). Research Journal of Pharmaceutical, Biological and Chemical Sciences 7(6):3201-3206.

Juggins, S. 2007. C2 Version 1.5 User guide. Software for ecological and palaeoecological data analysis and visualisation. Newcastle University, Newcastle upon Tyne, UK.

Krammer, K. and Lange-Bertalot, H. 1986. Bacillariophyceae. 1. Teil: Naviculaceae: Suesswasserflora von Mitteleuropa. Gustav Fischer Verlag, Stuttgart, Jena, 976 pp.

Krammer, K. and Lange-Bertalot, H. 1988. Bacillariophyceae. 2. Teil: Bacillariaceae, Epitemiaceae, Surirellaceae: Suesswasserflora von Mitteleuropa. Gustav Fischer Verlag, Stuttgart, Jena, 596 pp.

Krammer, K. and Lange-Bertalot, H. 1991. Bacillariophyceae. 3. Teil: Centrales, Fragilariaceae, Eunotiaceae: Suesswasserflora von Mitteleuropa. Gustav Fischer Verlag, Stuttgart, Jena, $576 \mathrm{pp}$.

Kumke, T., Kienel, U., Weckström, J., Korhola, A., and Hubberten, H. W. 2004. Inferred Holocene palaeotemperatures from diatoms at Lake Lama, Central Siberia. Arctic Antarctic and Alpine Research 36:626-636. https://doi. org/10.1657/1523-0430(2004)036[0624:IHPFDA]2.0. $\mathrm{CO} ; 2$

Mukhin, N. I., Petrakova, V. M., and Shevchenko, A. I. 1964. Climatic characteristics of the Pechora coal basin. In Geocryological conditions of the Pechora coal basin. pp. 2028 Moscow. (In Russian)

Nazarova L., Semenov V. F., Sabirov R. M., and Efimov I. Y. 2004. The state of bentic communities and water quality of Cheboksar Water reservoir. Water Resources 31(3):347-353. https://doi.org/10.1023/B:WARE. 0000028702.74325.c5

Nazarova, L., Lüpfert, H., Subetto, D., Pestryakova, L., and Diekmann, B., 2013. Holocene climate conditions in Central Yakutia (North-Eastern Siberia) inferred from sediment composition and fossil chironomids of Lake Temje. Quaternary International 290-291:264-274. https://doi.org/10.1016/j.quaint.2012.11.006

Nazarova, L., Bleibtreu, A., Hoff, U., Dirksen, V., and Diekmann, B. 2017a. Changes in temperature and water depth of a small mountain lake during the past 3000 years in Central Kamchatka reflected by chironomid record. Quaternary International 447:46-58. https:// doi.org/10.1016/j.quaint.2016.10.008

Nazarova, L. B., Self, A.E., Brooks, S.J., Solovieva, N., Syrykh, L. S., and Dauvalter, V.A. 2017b. Chironomid fauna of the lakes from the Pechora River basin (East of European part of Russian Arctic): ecology and reconstruction of recent ecological changes in the region. Contemporary Problems of Ecology 10(4):350-362. https://doi. org/10.1134/S1995425517040059
Palagushkina, O. V., Nazarova, L. B., Wetterich, S., and Shirrmaister, L. 2012. Diatoms of modern bottom sediments in Siberian Arctic. Contemporary Problems of Ecology 5(4):413-422. https://doi.org/10.1134/ S1995425512040105

Palagushkina, O., Wetterich, S., Schirrmeister, L., and Nazarova, L. 2017a. Modern and fossil diatom assemblages from Bol'shoy Lyakhovsky Island (New Siberian Archipelago, Arctic Siberia). Contemporary problems of Ecology 10(4):380-394. https://doi.org/10.1134/ S1995425517040060

Palagushkina, O., Wetterich, S., Biskaborn, B., Nazarova, L., Lenz, J., Schwamborn, G., Schirrmeister, L., and Grosse, G. 2017b. Diatom records and tephra mineralogy in pingo deposits of Seward Peninsula, Alaska. Palaeogeography, Palaeoclimatology, Palaeoecology 479:1-15. https://doi.org/10.1016/j.palaeo.2017.04.006

Pielou, E. C. 1966. The measurement of diversity in different types of biological collections. Journal of theoretical biology 13:131-144. https://doi.org/10.1016/00225193(66)90013-0

Plikk, A., Engels, S., Luoto, T., Nazarova, L., Salonen, J. S., and Helmens, K. F. 2019. Chironomid-based temperature reconstruction for the Eemian Interglacial (MIS 5e) at Sokli, northeast Finland. Journal of Paleolimnology 61(3):355371. https://doi.org/10.1007/s10933-018-00064-y

Puusepp, L. and Kangur, M. 2010. Linking diatom community dynamics to changes in terrestrial vegetation: a palaeolimnological case study of Lake Kūzi, Vidzeme Heights (Central Latvia). Estonian Journal of Ecology 59(4):259280. https://doi.org/10.3176/eco.2010.4.02

R Core Team. 2012. R Development Core Team, 2012. R: a Language and Environment for Statistical Computing. $\mathrm{R}$ Foundation for Statistical Computing, Vienna, Austria

Reynolds, C.S. 2003. The development of perceptions of aquatic eutrophication and its control. Ecohydrology Hydrobiologe 3(2):149-163.

Rouillard, A., Michelutti, N., Rosén, P., Douglas, M. S. V., and Smol, J. P. 2012. Using paleolimnology to track Holocene climate fluctuations and aquatic ontogeny in poorly buffered High Arctic lakes. Palaeogeography, Palaeoclimatology, Palaeoecology 321-322:1-15. https://doi. org/10.1016/j.palaeo.2012.01.011

Rühland, K. and Smol, J. P. 2005. Diatom shifts as evidence for recent Subarctic warming in remote tundra lake, NWT, Canada. Palaeogeography, Palaeoclimatology, Palaeoecology 226(1-2):1-16. https://doi.org/10.1016/j.palaeo.2005.05.001

Shannon, C. E. and Weaver, W. 1963. The mathematical theory of communication. Urbana: University of Illinois Press $117 \mathrm{pp}$.

Smol, J.P., Wolfe, A.P., Birks, H.J.B., Douglas, M.S. V., Jones, V. J., Korhola, A., Pienitz, R., Rühland, K., Sorvari, S., Antoniades, D., Brooks, S. J., Fallu, M.-A., Hughes, M., Keatley, B., Laing, T., Michelutti, N., Nazarova, L., Nyman, M., Paterson, A. M., Perren, B., Quinlan, R., Rautio, M., Saulnier-Talbot, É., Siitonen, S., Solovieva, and N., Weckström, J. 2005. Climate-driven regime shifts in the biological communities of Arctic lakes. Proceedings of the National Academy of Sciences USA 102(12):4397-4402. https://doi.org/10.1073/pnas.0500245102

Solovieva, N., Jones, V.J., Nazarova, L., Brooks, S.J., Birks, H.J. B., Grytnes, J.-A., Appleby, P. G., Kauppila, T., Kondratenok, B., Renerg, I., and Ponomarev V. 2005. Paleolimnological evidence for recent climatic change in lakes from the northern Urals, arctic Russia. Journal of Paleolimnology 33(4):463-482. https://doi.org/10.1007/ s10933-005-0811-3 
Solovieva, N., Jones, V. J., Birks, J. H. B., Appleby, P., and Nazarova, L. 2008. Diatom responses to 20 th century climate warming in lakes from the northern Urals, Russia. Palaeogeography, Palaeoclimatology, Palaeoecology 259(23):96-106. https://doi.org/10.1016/j.palaeo.2007.10.001

Solovieva, N., Klimaschewski, A., Self, A. E., Jones, V.J., Andrén, E., Andreev, A. A., Hammarlund, D., Lepskaya, E. V., and Nazarova, L. 2015. Holocene environmental history of a small coastal lake from north-eastern Kamchatka Peninsula. Global and Planetary Change 134:55-66. https://doi.org/10.1016/j.gloplacha.2015.06.010

Stenina, A. S. and Gezen, M. I. 1975. Diatoms in the plankton of tundra Harbey Lakes (Komi Autonomous Soviet Socialist Republic). Botanical Journal 60(6):1178-1183. (In Russian)

Stenina, A. S. 1978. Features of the flora of the eastern part of the Bolshezemelskaya tundra. Diatoms. pp. 21-26. In: Flora and fauna of reservoirs of the European North. Science, Leningrad. (In Russian)

Stenina, A. S. 2009. Diatoms in the lakes of the east of the Bolshezemelskaya tundra. 174 pp. Syktyvkar. (In Russian)

Subetto, D. A., Nazarova, L. B., Pestryakova, L. A., Syrykh, L. S., Andronikov, A.V., Biskaborn, B., Diekmann, B., Kuznetsov, D. D., Sapelko, T. V., and Grekov, I. M. 2017. Palaeolimnological studies in Russian Northern Eurasia: A review. Contemporary problems of Ecology 10(4):327335. https://doi.org/10.15372/SEJ20170401

Syrykh, L. S., Nazarova, L. B., Herzschuh, U., Subetto, D. A., and Grekov, I. M. 2017. Reconstruction of palaeoecological and palaeoclimatic conditions of the Holocene in the south of Taimyr according to the analysis of lake sedi- ments. Contemporary problems of Ecology 10(4):363-369. https://doi.org/10.1134/S1995425517040114

Teteryuk, B. Yu. 2012. Flora of ancient lakes of the European northeast of Russia. In Proceedings of the Samara Scientific Center of the Russian Academy of Sciences. 14(1):82-90. (In Russian)

Trifonova, I. S. and Afanasyeva, A. L. 2008. Long-term changes in the phytoplankton of Lake Krasnoye. In Long-term changes in the biological communities of the mesotrophic lake under climatic fluctuations and eutrophication. 246 pp. LEMA Publishing House, St. Petersburg. (In Russian)

Van Dam, H., Mertens, A., and Sinkeldam, J., 1994. A coded checklist and ecological indicator values of freshwater diatoms from the Netherlands. Aquatic Ecology 28(1):117-133. https://doi.org/10.1007/BF02334251

Vlasova, T.A. 1976. Hydrological and hydrochemical conditions of biological production in the lakes of Harbey system. In Productivity of the lakes of the eastern part of the Bolshezemelskaya tundra. pp. 6-32. Science, Leningrad. (In Russian)

Weckstrom, J., Korhola, A., and Blom, T. 1997. Diatoms as quantitative indicators of $\mathrm{pH}$ and water temperature in subarctic Fenoscandian lakes. Hydrobiologia 347(12):171-184. https://doi.org/10.1023/A:1003091923476

Wetterich, S., Schirrmeister, L., Nazarova, L., Palagushkina, O., Bobrov, A., Pogosyan, L., Savelieva, L., Syrykh, L., Matthes, H., Fritz, M., Gunther, F., and Opel, T. 2018. Holocene thermokarst and pingo development in the Kolyma Lowland 1 (NE Siberia). Permafrost and Periglacial Processes 29(3):182-198. https://doi.org/10.1002/ppp.1979 